\title{
Storage characteristics, nutritive value, and fermentation characteristics of alfalfa packaged in large-round bales and wrapped in stretch film after extended time delays ${ }^{1}$
}

\author{
W. K. Coblentz, ${ }^{* 2}$ K. P. Coffey, $†$ and E. A. Chow \\ *USDA-ARS, US Dairy Forage Research Center, Marshfield, WI 54449 \\ †Department of Animal Science, University of Arkansas, Fayetteville 72701 \\ ¥Kuraray America Inc., Pasadena, TX 77507
}

\begin{abstract}
The production of baled silage is attractive to producers because it offers advantages over dry hay, particularly by limiting risks associated with wet or unstable weather conditions. Our objectives were to test the effects of delayed wrapping on silage fermentation, storage characteristics, and the nutritive value of baled alfalfa silages. To accomplish this, large-round bales of alfalfa were wrapped in plastic film within $4 \mathrm{~h}$ of baling (d 0 ), or after delays of 1,2 , or $3 \mathrm{~d}$. A secondary objective was to evaluate a prototype bale wrap containing an $\mathrm{O}_{2}$-limiting barrier (OB) against an identical polyethylene wrap without the $\mathrm{O}_{2}$ barrier (SUN). Sixty-four $1.19 \times 1.25-\mathrm{m}$ bales of alfalfa were made from 4 field blocks at a mean moisture concentration of $59.1 \pm 4.3 \%$ with a mean initial wet bale weight of $473 \pm 26.4 \mathrm{~kg}$. Two bales per field block were assigned to each combination of bale wrap (SUN or OB) and wrapping time $(0,1,2$, or $3 \mathrm{~d}$ postbaling), and one bale of each pair was fitted with a thermocouple placed in the geometric center of each bale. All bales were sampled after a $97-d$ storage period. Internal bale temperatures, recorded at the time bales were wrapped, were greater for all bales with wrapping delays compared with bales wrapped on d 0 (54.9 vs. $\left.34.9^{\circ} \mathrm{C}\right)$, and increased to a maximum of $63.9^{\circ} \mathrm{C}$ after a 3 -d delay exhibiting a linear effect of time delay. Total silage fermentation acids (lactic, acetic, propionic, butyric, and isobutyric) were greatest when bales were wrapped on d 0 compared with all bales wrapped with time delays (4.64 vs. $2.26 \%$ of DM), and declined with linear and quadratic effects of wrapping delay. Total fermentation acids also were related

\footnotetext{
Accepted December 21, 2015.

${ }^{1}$ Mention of trade names or commercial products in this article is

${ }^{2}$ Corresponding author: wayne.coblentz@ars.usda.gov
}

Received September 10, 2015. solely for the purpose of providing specific information, and does not imply either recommendation or endorsement by the US Department of Agriculture.
\end{abstract}

quadratically to internal bale temperature by regression $\left[\mathrm{y}(\%\right.$ of $\left.\mathrm{DM})=0.0042 \mathrm{x}^{2}-0.50 \mathrm{x}+17.1 ; \mathrm{R}^{2}=0.725\right]$. Similar responses were observed for lactic acid, except that trends were linear, both for orthogonal contrasts evaluating length of wrapping delay, and in regressions on internal bale temperature $[\mathrm{y}(\%$ of $\mathrm{DM})=-0.046 \mathrm{x}$ $\left.+3.5 ; \mathrm{R}^{2}=0.663\right]$. Butyric acid also was detected, regardless of treatment, but was greatest within bales wrapped on d 0 compared with those with wrapping delays ( 0.99 vs. $0.38 \%$ of $\mathrm{DM}$ ), and a similar response (0.68 vs. $0.52 \%$ of $\mathrm{DM}$ ) was observed for $\mathrm{NH}_{3}-\mathrm{N}$, suggesting that clostridial activity occurred during silage fermentation. Based on these results, silage fermentation characteristics and the nutritive value declined with time delays before wrapping, but responses were exacerbated when delays exceeded $1 \mathrm{~d}$.

Key words: alfalfa, baled silage, oxygen barrier, wrapping delay

\section{INTRODUCTION}

The production of baled silage is attractive to many small or mid-sized dairy producers because it offers several advantages over conserving forages as dry hay. Perhaps the most important advantage is the reduced risk of rain damage to forage crops because the time requirement for wilting to a recommended moisture threshold for this silage type ( $\sim 5$ to $55 \%$; Shinners, 2003 ) is greatly reduced relative to the time required to wilt forages properly for conservation as dry hay. Other advantages over dry hay include (1) better retention of leaves from legume forages, and (2) potential for outside storage because the ensiled forage is wrapped completely in film, and therefore sheds water. However, silage fermentation within wrapped round-bales differs somewhat from precision-chopped silages. Typical moisture recommendations for baled silages range from 45 to $55 \%$ (Shinners, 2003), which is considerably drier than recommendations for precision-chopped alfalfa silages ( $\leq 70 \%$; Muck et al., 2003). This lower moisture 
may restrict the production of fermentation acids and limit the concomitant $\mathrm{pH}$ depression within the silage (Nicholson et al., 1991). Furthermore, the long-stem nature of baled forages restricts the release of sugars required for fermentation by lactic-acid-producing bacteria (Nicholson et al., 1991; Muck et al., 2003; Savoie and Jofriet, 2003), slowing the rate and limiting the extent of silage fermentation. This problem also may be exacerbated by the forage DM densities produced by round balers, which often are less than well-packed, precision-chopped silages.

Other factors also may affect the fermentation characteristics of round-bale silages. One such factor is the potential for delays in wrapping silages after baling is completed, which allows $\mathrm{O}_{2}$ access to the silage mass, and can cause increased internal bale temperatures, oxidation of water-soluble carbohydrates, a greater final silage $\mathrm{pH}$, and if wrapping delays are extended, formation of N-containing Maillard products that have poorer bioavailability within livestock than native forage $\mathrm{N}$ compounds or proteins (McBeth et al., 2001). Moshtaghi Nia and Wittenburg (2000) observed most of these responses following a 19-h wrapping delay when whole-crop barley silage was wrapped within 2, 10, or $19 \mathrm{~h}$ of baling; however, differences between 2and 10-h delays generally were minimal. Borreani and Tabacco (2008) have raised more subtle issues related to $\mathrm{O}_{2}$ infiltration based on the greater ratio of surface area to total silage DM in silage bales compared with chopped silages stored in bunkers or other large silo structures, as well as the somewhat permeable nature of bale wraps to $\mathrm{O}_{2}$, particularly when an inadequate number of polyethylene film layers are applied. Hancock and Collins (2006) evaluated the effect of polyethylene layers on preservation of alfalfa baled silage, determining that 2 wrapping layers was inadequate for preservation, but little advantage was gained by using more than 4 film layers within a 5-mo storage period in Kentucky. Permeability of film to $\mathrm{O}_{2}$ has the potential to stimulate aerobic microorganisms, including yeasts and molds, thereby resulting in DM losses and aerobic deterioration. Recently, Borreani and Tabacco (2008) found that insertion of an $\mathrm{O}_{2}$-limiting barrier within the polyethylene wrap reduced losses of DM during storage and had the potential to reduce the number of wrapping layers required for good fermentation and storage, which may provide a cost incentive to producers. Our objectives for this project were to test the effects of delayed wrapping on silage fermentation, storage characteristics, and the nutritive value of baled alfalfa silages. To accomplish this, large-round bales of alfalfa were wrapped in plastic film within $4 \mathrm{~h}$ of baling (d 0 ), or after delays of 1,2 , or $3 \mathrm{~d}$. A secondary objective was to evaluate a prototype bale wrap containing an $\mathrm{O}_{2}$-limiting barrier $(\mathbf{O B})$ against the identical polyethylene wrap without the $\mathrm{O}_{2}$ barrier (SUN).

\section{MATERIALS AND METHODS}

\section{Field, Storage, and Sampling Procedures}

Description of Field Site and Experimental Layout. An 8.0-ha site on the University of Wisconsin Marshfield Agricultural Research Station, located near Stratford, Wisconsin $\left(44^{\circ} 7^{\prime} \mathrm{N}, 90^{\circ} 1^{\prime} \mathrm{W}\right)$, was selected for the experiment. The field site was planted to Croplan Rebound 6.0 alfalfa (Winfield Solutions LLC, St. Paul, MN) at a seeding rate of $13.4 \mathrm{~kg} /$ ha during 2013. During 2014, the second cutting from this site was mowed at $25 \%$ bloom on August 5, 2014, with a 4.9-m-wide Case-International Harvester Model DC163 Hydroswing mower-conditioner (CNH Industrial America LLC, Racine, WI) equipped with metal conditioning rollers. Subsequently, the field was raked at $0930 \mathrm{~h}$ on August 7 with a Kuhn Model GA 4220 TH Masterdrive sidedelivery rake (Kuhn S.A., Saverne, France). Sixty-four round bales bound with net wrap (2 revolutions) were made between 1400 and $1600 \mathrm{~h}$ on the same day with a New Holland BR740A Crop Cutter round baler (CNH Industrial America LLC); the option for cutting alfalfa stems into shorter lengths was not engaged during this study. Prior to initiating the experiment, the field site was subdivided primarily on the basis of topography (slope), into 4 experimental blocks of approximately equal size (2 ha); therefore, a total of 16 bales were made per field block for the study.

Description of Experimental Treatments. Silage bale wraps used in this study included SUNFILM (750 mm $\times 1,500 \mathrm{~m} \times 25 \mu \mathrm{m}$; AEP Industries Inc., Mt. Top, PA), which is a commercially available product commonly used throughout the United States (SUN), and a prototype film produced identically, but with an $\mathrm{O}_{2}$-limiting barrier (Kuraray America Inc., Pasadena, TX) inserted within the wrap (OB). Oxygen transmission rates for a single layer measured at $1 \mathrm{~atm}$ of pressure, $20^{\circ} \mathrm{C}$, and $65 \%$ relative humidity were 6,931 and $198 \mathrm{~cm}^{3} / \mathrm{m}^{2} \cdot \mathrm{d}$ for SUN (MOCON Testing Service, Minneapolis, MN) and OB (Kuraray America Inc.), respectively. This study was designed as a randomized complete block with a $2 \times 4$ factorial arrangement of treatments that included 2 wrap types (SUN or OB) and 4 wrapping times (d 0 , or after $1-, 2-$, or 3 -d delays). As described, 8 treatment combinations were represented within each field block, and 2 bales were produced per block for each treatment combination. Treatment assignments within each block were randomized before the trial began, such that successive bales discharged from the baler were not assigned to 
like treatment combinations, unless dictated by the a priori randomization.

Initial Bale Processing and Sampling. All bales were measured and weighed $( \pm 0.2 \mathrm{~kg})$. For bales assigned to be wrapped without delay (d 0), four 0.61-mdeep core samples $(0.025-\mathrm{m}$ diameter) were obtained from one side of each bale at $1700 \mathrm{~h}$ using a Uni-Forage Sampler (Star Quality Samplers, Edmonton, AB, Canada) fitted to an electric drill. Air was purged from the sample holes with spray-foam insulation; however, filling of holes was terminated well before insulation was visible at the mouth of the sampling hole to prevent the wet foam insulation from directly contacting the polyethylene film when bales were wrapped shortly thereafter. All core samples were composited by bale $(\sim 350 \mathrm{~g} /$ bale; wet basis), sealed in 3.8-L plastic freezer bags, placed on ice in insulated coolers, and taken to the research laboratory, where a 50-g subsample was removed and dried overnight in a convection oven at $105^{\circ} \mathrm{C}$ to determine the moisture concentration of the forage within each bale. The remainder of the composite sample from each bale was immediately placed in an ultralow freezer $\left(-80^{\circ} \mathrm{C}\right)$ to suspend respiration pending further processing and analysis.

Beginning at $1800 \mathrm{~h}$ on August 7, bales assigned to be wrapped without delay (d 0) were wrapped with the assigned film type (SUN or OB), and placed on a concrete storage pad with an east to west orientation. Transport from the field, weighing, sampling, and wrapping represented an approximate 4-h time lag between baling and wrapping of these bales, which is consistent with good production management. Bales were not stacked on top of each other after they were wrapped. Silage wraps were applied with an individual (singlebale) wrapper (model 995 TSR, McHale Engineering Limited, Ballinrobe, Co. Mayo, Ireland) that was preprogramed to apply 7 film layers (28 table revolutions) to each bale. This wrapping protocol would be expected to provide good security for long-term storage, and is consistent with local production management whenever long-term (7 to $10 \mathrm{mo}$ ) storage is projected. Borreani and Tabacco (2008) have suggested that insertion of an $\mathrm{O}_{2}$-limiting barrier within polyethylene bale wraps has the potential to reduce the number of wrapping layers required for good fermentation and storage, thereby potentially providing a cost incentive to producers. Our wrapping protocol was intentionally selected to establish a conservative baseline for comparing reduced numbers of wrapping layers in future studies. Immediately after bale wrapping was completed, 1 of the 2 bales per block assigned to the same wrap type was fitted with a thermocouple that was placed in the geometric center of the bale. The small hole where the thermocouple wire exited the bale wrap was immediately covered with appropriate tape for repairing silage plastics; wrapped bales were inspected weekly throughout the storage period to ensure the integrity of the tape covering this exit hole.

Processing and sampling procedures for bales assigned to 1-, 2-, or 3-d time delays were conducted similarly, beginning with core sampling at $1300 \mathrm{~h}$ and wrapping with film at $1400 \mathrm{~h}$ daily. Therefore, initial bale weights and all other chemical analyses conducted on a prestorage basis represent the forage or conditions within the bale at the time each bale was wrapped, and not at the time it was baled. After wrapping, bales were monitored for internal bale temperature at approximately $1300 \mathrm{~h}$ daily with a handheld Omega 450 AKT Type K thermocouple thermometer (Omega Engineering, Stamford, CT) until the trial was terminated with a final sampling of all bales on November 13, 2014. Internal bale temperatures were then summarized to yield 3 temperature related response variables: (1) internal bale temperature at the time bales were wrapped, (2) maximum internal bale temperature, and (3) 23-d average temperature, which was based on the observation that no internal bale temperature exceeded $30^{\circ} \mathrm{C}$ beyond $23 \mathrm{~d}$ of storage.

\section{Poststorage Sampling}

Procedures for processing silage bales after a 97-d storage period were initiated by reweighing each silage bale. The film wrap was removed from 6 randomly selected bales to establish a mean correction factor (3.3 $\pm 0.12 \mathrm{~kg}$ ) that could be applied to all bales to correct final bale weights for the weight of the film wrap. After weighing, eight 0.61-m-deep core samples $(0.025-\mathrm{m}$ diameter) were taken from the side of the bale that was opposite where initial cores were obtained before storage. Core samples from each bale were composited $(\sim 600 \mathrm{~g})$, thoroughly mixed, and a $50-\mathrm{g}$ subsample was immediately dried overnight in a convection oven at $105^{\circ} \mathrm{C}$ to determine the final moisture concentration of each bale. Recoveries of DM following silage fermentation and storage were calculated from DM weights of each bale on a pre- and poststorage basis; because bales were sampled initially (pre-storage) at the time they were wrapped, calculated recoveries of DM represent storage efficiencies from the time of wrapping only, and do not reflect any respiratory losses before bale wrapping. The remainder of each silage sample was sealed in a plastic freezer bag and placed in an ultralow $\left(-80^{\circ} \mathrm{C}\right)$ freezer to suspend respiration pending further analysis of nutritive value, $\mathrm{pH}$, and silage fermentation products. 


\section{Laboratory Analyses}

Silage. On a pre-ensiled basis, a 25 -g subsample was removed from each sealed freezer bag after thorough mixing, and initial $\mathrm{pH}$ of each bale was determined by adding $100 \mathrm{~mL}$ of deionized water and macerating for $30 \mathrm{~s}$ in a kitchen blender. The macerated contents were then filtered through 2 layers of cheesecloth, and the $\mathrm{pH}$ was determined with a bench-top $\mathrm{pH}$ meter (Orion3Star, Thermo Fisher Scientific Inc., Waltham, MA). The remaining portion of the composite sample from each bale $(\sim 275 \mathrm{~g})$ was lyophilized and then ground through a Thomas Model 4 Wiley Mill (Thomas Scientific, Swedesboro, NJ) fitted with a 1-mm screen. Ground, lyophilized samples were retained for subsequent analysis of nutritive value, buffering capacity (BC), water-soluble carbohydrates (WSC), and starch. Buffering capacity was reported as milliequivalents of $\mathrm{HCl}$ per kilogram of forage $\mathrm{DM}$ needed to reduce $\mathrm{pH}$ from 6.0 to 4.0 (Muck and Walgenbach, 1985; Coblentz and Muck, 2012). Water-soluble carbohydrates were extracted from a $0.25-\mathrm{g}$ ground subsample in $150 \mathrm{~mL}$ of deionized water for $2 \mathrm{~h}$, and then gravity-filtered through Whatman \#1 filter paper (GE Healthcare UK Limited, Little Chalfont, Buckinghamshire, UK). Concentrations of WSC were quantified using the phenol-sulfuric acid reaction, with final concentrations of WSC determined colorimetrically (Dubois et al., 1956). Concentrations of starch were determined by enzymatic hydrolysis of starch molecules with amyloglucosidase. D-Glucose monomers and $\mathrm{O}_{2}$ were converted by glucose oxidase to D-glucono- $\delta$-lactone and $\mathrm{H}_{2} \mathrm{O}_{2}$; subsequently, the $\mathrm{H}_{2} \mathrm{O}_{2}$ was oxidized electrochemically to yield a signal current (model 2700D Bioanalyzer, Yellow Springs Instrument Co., Yellow Springs, OH), which was calibrated to liberated peroxide from known standards (YSI, 2000).

For postensiled samples, sample processing and analysis procedures generally were similar to those described for pre-ensiled samples. However, BC was determined only on a pre-ensiled basis and omitted for all silage samples obtained after the 97-d storage period. Concentrations of fermentation products and $\mathrm{NH}_{3}-\mathrm{N}$ within all silage samples were determined by Cumberland Valley Analytical Services (Maugansville, $\mathrm{MD})$.

Nutritive Value. All lyophilized, ground forage samples were analyzed sequentially for NDF, ADF, hemicellulose, cellulose, and ADL using batch procedures outlined by Ankom Technology Corp. (Macedon, NY) for an Ankom200 Fiber Analyzer. Sodium sulfite and heat-stable $\alpha$-amylase were omitted from the NDF solution. Concentrations of total $\mathrm{N}$ within each sample were determined with a rapid combustion procedure (AOAC International, 1998; method 990.03; Elementar Americas Inc., Mt. Laurel, NJ), followed by conversion to $\mathrm{CP}$ using a factor of 6.25. Pools of $\mathrm{CP}$ that were insoluble in neutral and acid detergent (NDICP and ADICP, respectively) were determined similarly following nonsequential digestion in each respective solution. For this application, the NDF solution did not contain heat-stable $\alpha$-amylase or sodium sulfite, the latter of which was omitted because it cleaves disulfide bonds and dissolves cross-linked proteins, thereby reducing protein recovery from NDF residues (Van Soest et al., 1991). Whole-plant ash was determined by combusting 1.0-g samples of lyophilized forage in a muffle furnace at $500^{\circ} \mathrm{C}$ for $6 \mathrm{~h}$. Calculations of TDN for all forages were based on the summative equation (Weiss et al., 1992; NRC, 2001) using the ADL option for estimating truly digestible fiber.

\section{Statistics}

Data were analyzed by PROC MIXED of SAS (2010, version 9.3, SAS Institute Inc., Cary, NC) as a randomized complete block design with a $2 \times 4$ factorial arrangement of 2 silage wraps (OB or SUN) and 4 wrapping times (d 0 , or after $1-, 2-$, or 3 -d delays). There were 2 bales per treatment combination within each block, and blocks (4) were declared random throughout all analyses. Orthogonal contrasts were used to evaluate differences between wrapping time delays and wrap types: (1) delayed wrapping (1,2, or $3 \mathrm{~d}$ ) vs. control (d 0); (2) linear effect of wrapping delay; (3) quadratic effect of wrapping delay; and (4) OB vs. SUN. No evidence was found of an interaction between silage wraps and time delay across response variables; therefore, only main-effect means are reported and discussed. Furthermore, wrap types (OB vs. SUN) did not differ $(P \geq 0.072)$ for any response variable evaluated. As a result, mean comparisons for wrap types are reported in the tables, but are not discussed in the text.

Regressions of silage fermentation products or indices of nutritive value on internal bale temperatures at the time bales were wrapped in polyethylene film were conducted by PROC REG of SAS (2010). To conduct these regressions $(\mathrm{n}=32)$, the dependent variable (y-axis) represents the mean concentration calculated from the pair of like bales obtained from each interactive treatment combination within each field replication. The independent variable ( $\mathrm{x}$-axis) is the internal temperature measured within one bale within the same pair that was assigned a priori to be fitted with a thermocouple. Statistical significance was declared at the $P=0.05$ level of confidence. 


\section{RESULTS AND DISCUSSION}

\section{Bale Characteristics}

Prestorage. It should be emphasized that wet bale weights, initial DM concentrations of alfalfa forages, and calculated bale DM weights and DM densities were based on weights and core samples obtained immediately before silage wraps were applied (Table 1); therefore, any losses of DM via respiration that occurred before wrapping are not directly quantified. The only difference between treatments for initial bale characteristics was associated with wet bale weights, which were greater for bales wrapped on d 0 compared with those wrapped after a time delay (488 vs. $468 \mathrm{~kg} ; P=0.005$ ). Wet bale weights also declined linearly $(P<0.001)$ as the time delay was extended. However, these responses were not detected $(P \geq 0.349)$ when bale weights were reported on a DM basis.

Overall, the mean initial bale moisture concentration (59.1\%) was slightly greater than the range (45 to $55 \%$ ) suggested by Shinners (2003), but was well within the scope of many recent baled silage experiments (Nicholson et al., 1991; McCormick et al., 1998; Han et al., 2004; Hancock and Collins, 2006). Increasing the moisture concentration within silages positively affects the rate of fermentation, as well as concentrations and proportions of various fermentation products, which result in a more acidic final silage $\mathrm{pH}$ (Muck, 1990). The mean DM density of all silage bales (134 kg of $\mathrm{DM} / \mathrm{m}^{3}$ ) was somewhat less than reported by Han et al. (2004; 167 to $207 \mathrm{~kg}$ of $\mathrm{DM} / \mathrm{m}^{3}$ ), Hancock and Collins
(2006; 187 to $207 \mathrm{~kg}$ of $\mathrm{DM} / \mathrm{m}^{3}$ ), or Coblentz et al. (2014; 151 to $210 \mathrm{~kg}$ of $\mathrm{DM} / \mathrm{m}^{3}$ ) in other experiments with alfalfa baled silage. Extension recommendations often encourage the production of dense silage bales to improve fermentation and storage efficiency, primarily by eliminating air from the silage mass. A frequently mentioned target for DM density of baled silages is 162 $\mathrm{kg}$ of $\mathrm{DM} / \mathrm{m}^{3}$ (10 lb of $\mathrm{DM} / \mathrm{ft}^{3}$; Jennings, 2011), which often can be increased by slowing ground speed during baling operations. Our relatively low DM densities likely resulted from a procedural compromise in which baler ground speed was maintained at a rate suitable to produce 64 bales in less than $2 \mathrm{~h}$, thereby avoiding the creation of a bale moisture gradient across field blocks.

\section{Poststorage Bale Characteristics}

Final wet bale weights (Table 2) were greater for bales wrapped the same day as baling compared with those wrapped after a 1-, 2-, or 3-d time delay (467 vs. $453 \mathrm{~kg} ; P=0.025)$, and final wet bale weights declined linearly $(P=0.001)$ with increasing time delay. Final concentrations of bale moisture tended to exhibit a linear decline with wrapping time delay $(P=0.058)$. Neither the amount of DM recovered per bale (overall mean $=184 \mathrm{~kg}$ of DM; $P \geq 0.178)$, nor the percentage of DM recovered (overall mean $=95.6 \% ; P \geq 0.074$ ), were affected by treatment; however, the DM recovery for bales wrapped on d 0 tended to differ from those wrapped with 1-, 2-, or 3-d time delays (93.3 vs. $96.4 \%$; $P=0.074)$.

Table 1. Physical characteristics ${ }^{1,2}$ of 64 alfalfa silage bales at the time of wrapping in stretch film with (OB) or without (SUN) an $\mathrm{O}_{2}$-limiting barrier, and after wrapping delays as long as $3 \mathrm{~d}$

\begin{tabular}{|c|c|c|c|c|c|c|c|}
\hline Treatment & $\begin{array}{l}\text { Width, } \\
\text { m }\end{array}$ & $\begin{array}{c}\text { Diameter, } \\
\mathrm{m}\end{array}$ & $\underset{\mathrm{m}^{3}}{\text { Volume }}$ & $\begin{array}{l}\text { Wet weight, } \\
\text { kg }\end{array}$ & $\begin{array}{c}\text { Bale moisture, } \\
\%\end{array}$ & $\begin{array}{l}\text { DM weight, } \\
\text { kg of DM }\end{array}$ & $\begin{array}{l}\text { DM density, } \\
\mathrm{kg} \text { of } \mathrm{DM} / \mathrm{m}^{3}\end{array}$ \\
\hline \multicolumn{8}{|l|}{ Wrapping delay, $\mathrm{d}$} \\
\hline 0 & 1.20 & 1.25 & 1.46 & 488 & 59.6 & 197 & 135 \\
\hline 2 & 1.19 & 1.24 & 1.45 & 460 & 56.6 & 199 & 138 \\
\hline 3 & 1.18 & 1.25 & 1.45 & 459 & 59.1 & 187 & 130 \\
\hline SEM & 0.008 & 0.006 & 0.020 & 6.6 & 1.10 & 4.7 & 3.6 \\
\hline SUN & 1.19 & 1.25 & 1.45 & 476 & 59.2 & 194 & 134 \\
\hline SEM & 0.007 & 0.004 & 0.016 & 5.2 & 0.83 & 3.3 & 2.6 \\
\hline \multicolumn{8}{|l|}{ Contrast $^{3}(P>F)$} \\
\hline (1) Delay vs. control & 0.113 & 0.894 & 0.470 & 0.005 & 0.566 & 0.349 & 0.575 \\
\hline (2) Delay: linear & 0.296 & 0.882 & 0.616 & $<0.001$ & 0.207 & 0.355 & 0.560 \\
\hline (3) Delay: quadratic & 0.471 & 0.723 & 0.572 & 0.991 & 0.589 & 0.656 & 0.570 \\
\hline (4) OB vs. SUN & 0.464 & 0.933 & 0.726 & 0.444 & 0.887 & 0.824 & 0.752 \\
\hline
\end{tabular}

${ }^{1}$ Bale width and diameter measured immediately after baling; bale volume calculated on the basis of those measurements.

${ }^{2}$ Bale weight, dry weight, and DM density were determined at the time bales were wrapped in film, and do not include any changes that may have occurred during the delay before wrapping.

${ }^{3}$ Contrasts: (1) delay vs. control, bales wrapped after a 1-, 2-, or 3-d delay vs. those wrapped the same day they were baled; (2) delay: linear, linear effect of wrapping delay; (3) delay: quadratic, quadratic effect of wrapping delay; and (4) OB vs. SUN wrap. 
Table 2. Temperature and poststorage physical characteristics of 64 alfalfa silage bales wrapped in stretch film with (OB) or without (SUN) an $\mathrm{O}_{2}$-limiting barrier, and after wrapping delays as long as $3 \mathrm{~d}$

\begin{tabular}{|c|c|c|c|c|c|c|c|}
\hline Treatment & $\begin{array}{c}\text { Wet weight, } \\
\mathrm{kg}\end{array}$ & Bale moisture, & $\begin{array}{c}\text { DM recovered, } \\
\text { kg }\end{array}$ & $\begin{array}{c}\text { DM recovery, } \\
\%\end{array}$ & \multicolumn{3}{|c|}{ Internal bale temperature, ${ }^{1}{ }^{\circ} \mathrm{C}$} \\
\hline 0 & 467 & 60.7 & 183 & 93.3 & 34.9 & 38.1 & 29.7 \\
\hline 1 & 467 & 61.0 & 182 & 96.6 & 47.3 & 49.2 & 33.9 \\
\hline 2 & 445 & 56.9 & 191 & 96.3 & 53.5 & 59.3 & 37.7 \\
\hline 3 & 447 & 59.7 & 180 & 96.2 & 63.9 & 66.7 & 39.6 \\
\hline $\mathrm{OB}$ & 453 & 59.5 & 183 & 95.5 & 49.7 & 53.1 & 35.4 \\
\hline SUN & 460 & 59.7 & 185 & 95.6 & 50.1 & 53.6 & 35.1 \\
\hline SEM & 4.7 & 0.70 & 2.7 & 1.20 & 0.80 & 0.69 & 0.33 \\
\hline \multicolumn{8}{|l|}{ Contrast $^{2}(P>F)$} \\
\hline (1) Delay vs. control & 0.025 & 0.122 & 0.799 & 0.074 & $<0.001$ & $<0.001$ & $<0.001$ \\
\hline (2) Delay: linear & 0.001 & 0.058 & 0.953 & 0.203 & $<0.001$ & $<0.001$ & $<0.001$ \\
\hline (3) Delay: quadratic & 0.831 & 0.147 & 0.178 & 0.248 & 0.338 & 0.066 & 0.008 \\
\hline
\end{tabular}

${ }^{1}$ Internal bale temperature: maximum, maximum temperature recorded on any day during the 99-d storage period; 23-d average, and mean bale temperature during the first $23 \mathrm{~d}$ of storage.

${ }^{2}$ Contrasts: (1) delay vs. control, bales wrapped after a 1-, 2-, or 3-d delay vs. those wrapped the same day they were baled; (2) delay: linear, linear effect of wrapping delay; (3) delay: quadratic, quadratic effect of wrapping delay; and (4) OB vs. SUN wrap.

\section{Internal Bale Temperatures}

Internal bale temperatures (Table 2) responded predictably to extended exposure to air before wrapping, with availability of $\mathrm{O}_{2}$ supporting continuing respiration within the bale that resulted in sharply elevated internal bale temperatures. The internal bale temperature for the positive $(0-d)$ control was less than those bales wrapped after extended time delays $\left(34.9\right.$ vs. $54.9^{\circ} \mathrm{C}$; $P<0.001)$, and temperatures increased linearly $(P<$ $0.001)$ with length of delay. Similar responses were observed for maximum internal bale temperature, which generally occurred 1 to $3 \mathrm{~d}$ after bales were wrapped, and was an average of $3.5^{\circ} \mathrm{C}$ greater across all bales compared with temperatures measured at the time of wrapping. No bale exceeded the $30^{\circ} \mathrm{C}$ threshold commonly associated with formation of Maillard products in heated hays (Coblentz et al., 2010) or silages for more than $23 \mathrm{~d}$; however, internal bale temperatures subsided more slowly after wrapping following longer time delays. This observation is reflected in $23-\mathrm{d}$ mean bale temperatures, which were about $10^{\circ} \mathrm{C}$ greater for a 3 -d delay compared with no delay, and increased with strong linear $(P<0.001)$ and quadratic $(P=0.008)$ effects of time delay.

\section{Prestorage Ensiling Characteristics}

The $\mathrm{pH}$ of baled alfalfa forages at the time they were wrapped with film did not vary (overall mean $=6.22 ; P$ $\geq 0.459$ ) on the basis of time delay (Table 3 ). Buffering capacity was greater when wrapping was delayed for 1 , 2 , or $3 \mathrm{~d}$ compared with no delay (480 vs. $421 \mathrm{mEq}$ ) $\mathrm{kg}$ of DM; $P<0.001)$, and it increased in a strong linear $(P<0.001)$ relationship with length of wrapping delay. These results suggest that alfalfa becomes more highly buffered when spontaneous heating occurs before bale wrapping, thereby compounding an existing obstacle to good silage fermentation. Legumes in general, and alfalfa specifically, are known to be buffered more extensively than grasses, largely because of greater concentrations of organic acids, and to a lesser extent, proteins (McDonald et al., 1991). Several factors are known to reduce BC in alfalfa, most of which are consistent with poorer forage quality, such as plant maturity, stem percentage, and rain damage (Muck and Walgenbach, 1985; Coblentz and Muck, 2012). Conceptually, wrapping delays also should affect nutritive value negatively, primarily through respiration of sugars, which indirectly increases concentrations of forage fiber components (Rotz and Muck, 1994). However, the net effect of respiratory activity on BC was a sharp $(21 \%)$ increase after a 3 -d delay in wrapping compared with the positive $(0-\mathrm{d})$ control.

Concentrations of WSC (Table 3) were greater when bales were wrapped in film within $4 \mathrm{~h}$ of baling compared with bales wrapped after a time delay ( 5.3 vs. $4.4 \% ; P<0.001)$; in addition, WSC declined linearly $(P<0.001)$ with the length of time delay. Responses for concentrations of starch were similar, with an overall linear $(P=0.027)$ effect of time delay detected. However, unlike concentrations of WSC, bales wrapped 
Table 3. Prestorage ensiling characteristics for 64 large-round bales of alfalfa baled silage wrapped in stretch film either with (OB) or without (SUN) an $\mathrm{O}_{2}$-limiting barrier, and after wrapping delays as long as $3 \mathrm{~d}^{1}$

\begin{tabular}{|c|c|c|c|c|}
\hline Treatment & Initial pH & $\begin{array}{c}\text { Buffering capacity, } \\
\mathrm{mEq} / \mathrm{kg} \text { of } \mathrm{DM}\end{array}$ & $\begin{array}{l}\mathrm{WSC}^{2} \\
\% \text { of } \mathrm{DM}\end{array}$ & $\begin{array}{l}\text { Starch, } \\
\text { \% of DM }\end{array}$ \\
\hline \multicolumn{5}{|l|}{ Wrapping delay, $\mathrm{d}$} \\
\hline 0 & 6.25 & 421 & 5.3 & 0.68 \\
\hline 1 & 6.18 & 451 & 4.6 & 0.66 \\
\hline 2 & 6.23 & 479 & 4.5 & 0.55 \\
\hline 3 & 6.22 & 510 & 4.0 & 0.57 \\
\hline SEM & 0.059 & 6.1 & 0.14 & 0.044 \\
\hline \multicolumn{5}{|l|}{ Wrap type } \\
\hline OB & 6.24 & 461 & 4.6 & 0.62 \\
\hline SUN & 6.20 & 469 & 4.6 & 0.61 \\
\hline SEM & 0.050 & 4.3 & 0.14 & 0.032 \\
\hline \multicolumn{5}{|l|}{ Contrast $^{3}(P>F)$} \\
\hline (1) Delay vs. control & 0.459 & $<0.001$ & $<0.001$ & 0.080 \\
\hline (2) Delay: linear & 0.813 & $<0.001$ & $<0.001$ & 0.027 \\
\hline (3) Delay: quadratic & 0.586 & 0.960 & 0.292 & 0.590 \\
\hline (4) OB vs. SUN & 0.263 & 0.175 & 0.488 & 0.914 \\
\hline
\end{tabular}

${ }^{1}$ Bale moisture, initial $\mathrm{pH}, \mathrm{BC}$, WSC and starch were determined at the time bales were wrapped in film, and reflect any changes that occurred during the structured delay periods before wrapping.

${ }^{2}$ WSC, water-soluble carbohydrates.

${ }^{3}$ Contrasts: (1) delay vs. control, bales wrapped after a 1-, 2-, or 3-d delay vs. those wrapped the same day they were baled; (2) delay: linear, linear effect of wrapping delay; (3) delay: quadratic, quadratic effect of wrapping delay; and (4) OB vs. SUN wrap.

promptly compared with those wrapped following a time delay only tended to differ (0.68 vs. $0.59 \% ; P=$ 0.080 ) with respect to concentrations of starch.

Under ideal conditions, alfalfa is difficult to ensile because of its high BC and relatively low concentrations of the WSC that are required for production of lactic acid as the principal desired fermentation product (McDonald et al., 1991). Based on these results, time delays before bales are wrapped make ensiling alfalfa even more challenging because of the strong linear effects on both BC and WSC, which were positive and negative, respectively. Wrapping following any significant time delay results in an alfalfa forage that is more resistant to $\mathrm{pH}$ change and has less WSC available as substrate for production of silage fermentation acids, thereby increasing the problematic nature of silage fermentation.

\section{Regressions of WSC and BC on Internal Bale Temperature}

The relatively clear cause-and-effect relationship between wrapping delay and internal bale temperature for these silage bales has been described (Table 2). This spontaneous heating response occurs primarily via respiration of nonstructural carbohydrate into $\mathrm{CO}_{2}, \mathrm{H}_{2} \mathrm{O}$, and heat (Rotz and Muck, 1994), and is commonly observed in moist hays stored in large-round bales (Coblentz and Hoffman, 2009a). Figure 1 depicts the inverse relationship between pre-ensiled concentrations of WSC and the internal bale temperature at the time film wrap was applied $\left(\mathrm{y}=-0.039 \mathrm{x}+6.5 ; \mathrm{R}^{2}=0.634\right.$;
$P<0.001$ ), and illustrates the declining pool of WSC available to support silage fermentation whenever bales are not wrapped promptly. In contrast, a positive linear relationship $\left(\mathrm{y}=2.98 \mathrm{x}+316 ; \mathrm{R}^{2}=0.759 ; P<0.001\right)$ was observed between $\mathrm{BC}$ and internal bale temperature (Figure 2), which to our knowledge has not been demonstrated previously. Within this study, both of the previously stated limitations for alfalfa silage fermentation (low concentrations of WSC, high BC) were clearly exacerbated as simple linear functions of respiratory heat production before bale wrapping.

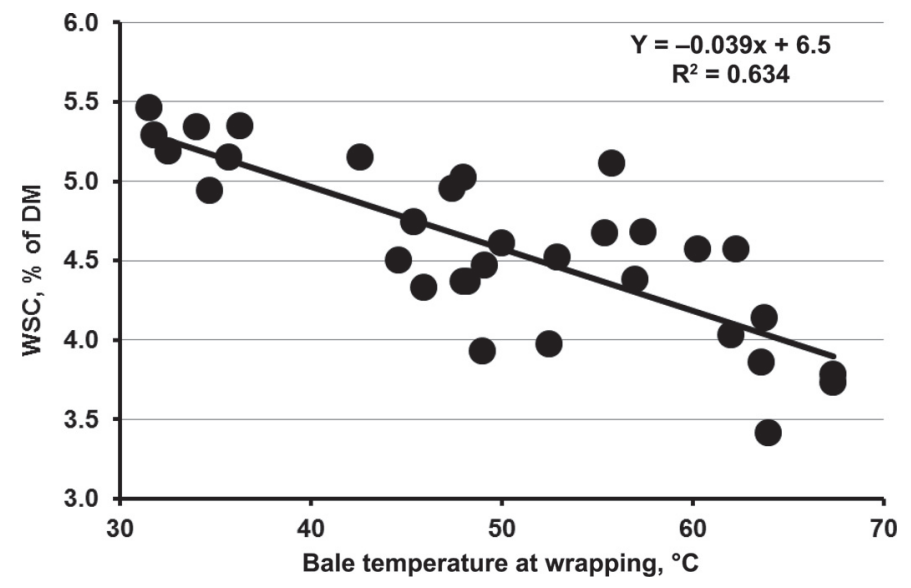

Figure 1. Linear regression of water-soluble carbohydrates (WSC) on internal bale temperature at the time alfalfa silage bales were wrapped with polyethylene films containing either an $\mathrm{O}_{2}$ barrier or no barrier at Marshfield, Wisconsin. 


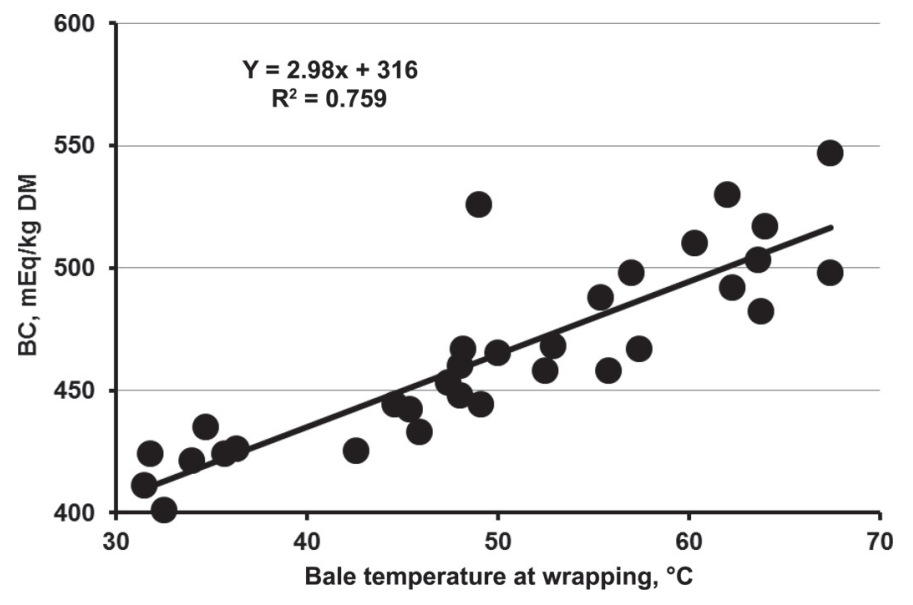

Figure 2. Linear regression of buffering capacity (BC) on internal bale temperature at the time alfalfa silage bales were wrapped with polyethylene films containing either an $\mathrm{O}_{2}$ barrier or no barrier at Marshfield, Wisconsin.

\section{Silage Fermentation Characteristics}

$\mathbf{N H}_{3}-\boldsymbol{N}$. On a percentage of DM basis, concentrations of $\mathrm{NH}_{3}-\mathrm{N}$ in these fermented alfalfa silages (Table 4) were greater in bales wrapped without delay compared with those wrapped 1,2 , or $3 \mathrm{~d}$ after baling (0.68 vs. $0.52 \% ; P<0.001)$. Concentrations of $\mathrm{NH}_{3}-\mathrm{N}$ declined from 0.68 to $0.44 \%$ when wrapping was delayed by $2 \mathrm{~d}$, but increased to $0.57 \%$ after a 3 -d delay, which resulted in both linear $(P=0.001)$ and quadratic $(P<0.001)$ overall effects of wrapping delay. Overall, $\mathrm{NH}_{3}-\mathrm{N}$ comprised between 12.4 and $19.0 \%$ of the total $\mathrm{N}$ within our baled silages. A common management target for $\mathrm{NH}_{3}-\mathrm{N}$ is $\leq 12 \%$ of silage $\mathrm{N}$ (McDonald and Edwards, 1976; Mahanna and Chase, 2003); however, larger percentages are indicative of undesirable activity of proteolytic clostridia within the silages (McDonald et al., 1991).

Final $\boldsymbol{p H}$. The final $\mathrm{pH}$ of alfalfa silages (Table 4) was most acidic when wrapping occurred on $\mathrm{d} 0$ or after a 1-d delay. Overall, delayed wrapping $(1,2$, or $3 \mathrm{~d}$ ) resulted in a greater final $\mathrm{pH}$ than bales wrapped promptly after baling (5.78 vs. $5.70 ; P=0.004$ ); in addition, final $\mathrm{pH}$ increased with both linear $(P<$ $0.001)$ and quadratic $(P=0.010)$ effects of wrapping delay, demonstrating an increase of $0.1 \mathrm{pH}$ unit per $\mathrm{d}$ for bales wrapped after 2 or $3 \mathrm{~d}$ compared with those wrapped 1-d postbaling. Reports describing the effects of wrapping delay on final silage $\mathrm{pH}$ are limited; however, Moshtaghi Nia and Wittenburg (2000) reported a less acidic $\mathrm{pH}$ for barley silages sampled after $64 \mathrm{~d}$ of storage whenever the initial bale wrapping was delayed for $19 \mathrm{~h}(\mathrm{pH}=5.69)$ compared with 2 or $10 \mathrm{~h}$, whose responses were similar (mean $\mathrm{pH}=4.77$ ). Although not tested statistically, it is interesting that the final $\mathrm{pH}$ for bales wrapped without time delay and those wrapped after $1 \mathrm{~d}$ were very similar (5.70 and 5.68, respectively), especially given the large advantages observed for production of total acids (4.63 vs. 3.19\%), lactic acid (1.88 vs. 1.59\%), and acetic acid (1.47 vs. $0.77 \%$ ) by bales wrapped without time delay. However, acetic and butyric acids are weaker than lactic acid, and formation of butyric acid often comes at a cost of 2 lactic acid molecules, all of which may have contributed to this observation.

Silage Fermentation Acids. Total fermentation acids (Table 4) were greater for bales wrapped the same day baling occurred compared with bales wrapped after a time delay (4.64 vs. $2.26 \%$; $P<0.001$ ), and concentrations of total acids declined with linear $(P<0.001)$ and quadratic $(P<0.001)$ effects of time delay. Concentrations of lactic acid were greatest in bales wrapped without time delay (1.88 vs. $1.00 \% ; P<0.001$ ), and declined in a strong linear $(P<0.001)$ pattern with the length of time delay, reaching a minimum of $0.67 \%$ after 3 d. In contrast to concentrations of total fermentation acids, lactic acid did not demonstrate a quadratic effect $(P=0.180)$ of time delay. The linear decline in production of lactic acid is largely predictable because WSC is a required substrate, and sugars were oxidized during the respiratory activity that occurred during 1-, 2-, and 3-d wrapping delays.

The quadratic effect observed for production of total fermentation acids was likely associated with increased production of less desirable or undesirable fermentation acids, particularly after a 2-d wrapping delay. Within this context, overall linear $(P<0.001)$ and quadratic $(P \leq 0.021)$ effects were observed for declining concentrations of acetic, propionic, butyric, and isobutyric acids, with slight increases occurring in each case with a 3-d wrapping delay compared with a 2 -d delay. For bales wrapped without a time delay, production of acetic (1.47 vs. $0.76 \% ; P<0.001)$, propionic $(0.28$ vs. $0.07 \% ; P<0.001)$, and butyric $(0.99$ vs. $0.38 \% ; P<$ 0.001 ) acids was greater than in bales wrapped following time delays.

Of these less desirable or undesirable acids, the production of butyric acid is most problematic; this suggests significant activity by saccharolytic clostridia, which ferment sugars and organic acids, yielding butyric acid as a primary end product (McDonald et al., 1991). Elevated concentrations of both butyric acid and $\mathrm{NH}_{3}-\mathrm{N}$ (discussed previously) are consistent with greater clostridial activity within bales wrapped without time delay. Although circumstantial in nature, these observations are further corroborated by a tendency for poorer DM recoveries in bales wrapped without time delay compared with recoveries from bales where wrap- 
Table 4. Fermentation characteristics ${ }^{1}$ for 64 alfalfa silage bales wrapped in stretch film either with (OB) or without (SUN) an $\mathrm{O}_{2}$-limiting barrier, and after wrapping delays as long as $3 \mathrm{~d}$

\begin{tabular}{|c|c|c|c|c|c|c|c|c|c|c|c|}
\hline Treatment & $\begin{array}{l}\mathrm{NH}_{3}-\mathrm{N} \\
\% \text { of } \mathrm{DM}\end{array}$ & $\begin{array}{l}\mathrm{NH}_{3}-\mathrm{N} \\
\% \text { of } \mathrm{N}\end{array}$ & Final pH & $\begin{array}{c}\text { Total acids, } \\
\% \text { of DM }\end{array}$ & $\begin{array}{l}\text { Lactic, } \\
\% \text { of DM }\end{array}$ & $\begin{array}{l}\text { Acetic, } \\
\% \text { of DM }\end{array}$ & $\begin{array}{l}\text { Propionic, } \\
\% \text { of DM }\end{array}$ & $\begin{array}{l}\text { Butyric, } \\
\% \text { of DM }\end{array}$ & $\begin{array}{l}\text { Isobutyric, } \\
\% \text { of DM }\end{array}$ & $\begin{array}{l}\text { Methanol, } \\
\% \text { of DM }\end{array}$ & $\begin{array}{l}\text { Ethanol, } \\
\% \text { of DM }\end{array}$ \\
\hline \multicolumn{12}{|l|}{ Wrapping delay, $\mathrm{d}$} \\
\hline 0 & 0.68 & 19.0 & 5.70 & 4.64 & 1.88 & 1.47 & 0.28 & 0.99 & 0.02 & 0.19 & 0.29 \\
\hline 1 & 0.54 & 15.0 & 5.68 & 3.13 & 1.59 & 0.77 & 0.10 & 0.67 & 0.01 & 0.20 & 0.16 \\
\hline 2 & 0.44 & 12.4 & 5.78 & 1.54 & 0.73 & 0.61 & 0.04 & 0.12 & 0.05 & 0.23 & 0.09 \\
\hline 3 & 0.57 & 16.2 & 5.89 & 2.11 & 0.67 & 0.91 & 0.08 & 0.35 & 0.11 & 0.24 & 0.09 \\
\hline SEM & 0.031 & 0.84 & 0.039 & 0.221 & 0.135 & 0.091 & 0.016 & 0.089 & 0.012 & 0.020 & 0.009 \\
\hline \multicolumn{12}{|l|}{ Wrap type } \\
\hline $\mathrm{OB}$ & 0.55 & 15.6 & 5.77 & 2.74 & 1.22 & 0.89 & 0.11 & 0.48 & 0.04 & 0.22 & 0.16 \\
\hline SUN & 0.56 & 15.8 & 5.76 & 2.96 & 1.22 & 0.98 & 0.14 & 0.57 & 0.05 & 0.21 & 0.16 \\
\hline SEM & 0.024 & 0.66 & 0.035 & 0.170 & 0.120 & 0.076 & 0.011 & 0.063 & 0.009 & 0.017 & 0.006 \\
\hline \multicolumn{12}{|l|}{ Contrast $^{2}(P>F)$} \\
\hline (1) Delay vs. control & $<0.001$ & $<0.001$ & 0.004 & $<0.001$ & $<0.001$ & $<0.001$ & $<0.001$ & $<0.001$ & 0.010 & 0.012 & $<0.001$ \\
\hline (2) Delay: linear & 0.001 & 0.003 & $<0.001$ & $<0.001$ & $<0.001$ & $<0.001$ & $<0.001$ & $<0.001$ & $<0.001$ & 0.002 & $<0.001$ \\
\hline (3) Delay: quadratic & $<0.001$ & $<0.001$ & 0.010 & $<0.001$ & 0.180 & $<0.001$ & $<0.001$ & 0.003 & 0.021 & 0.756 & $<0.001$ \\
\hline (4) OB vs. SUN & 0.714 & 0.758 & 0.592 & 0.279 & 0.999 & 0.231 & 0.072 & 0.314 & 0.347 & 0.414 & 0.969 \\
\hline
\end{tabular}

${ }^{1}$ Total fermentation acids were calculated as the sum of lactic, acetic, propionic, butyric, and isobutyric acids. Each silage sample also was analyzed for 2-butanol, methyl acetate, ethyl acetate, propyl acetate, ethyl lactate, propyl lactate, and 1,2-propanediol; however, each of these fermentation products were either not detectable or present in only trace concentrations.

¿ $\quad{ }^{2}$ Contrasts: (1) delay vs. control, bales wrapped after a 1-, 2-, or 3-d delay vs. those wrapped the same day they were baled; (2) delay: linear, linear effect of wrapping delay; (3) delay: quadratic, quadratic effect of wrapping delay; and (4) OB vs. SUN wrap. 
ping was delayed (93.3 vs. $96.4 \% ; P=0.074$; Table $2)$. Theoretically, an additional side effect of converting 2 lactate molecules into butyrate is a $51 \%$ loss of DM associated with that specific conversion, primarily through formation of $\mathrm{CO}_{2}, \mathrm{H}_{2}$, and $\mathrm{H}_{2} \mathrm{O}$ (McDonald et al., 1991). It remains unclear why evidence of clostridial activity was greatest when bales were wrapped without a time delay. However, this silage fermentation response could be related to a combination of factors, including (1) a moderately high moisture concentration $(59.6 \%)$ that slightly exceeded common recommendations for baled silage (45 to 55\%; Shinners, 2003), but was substantially less than recommendations for chopped alfalfa silage ( $\leq 70 \%$; Muck et al., 2003); (2) slower and less extensive silage fermentation in baled silages because the alfalfa was baled and sealed on a whole-plant basis that required diffusion of sugars to lactic-acid-producing bacteria adhered to the outside of the plants (Nicholson et al., 1991; Muck et al., 2003; Savoie and Jofriet, 2003); (3) a final pH that was insufficiently acidic to inhibit the activity of clostridial bacteria, which often is thought to occur at about $\mathrm{pH}$ $=4.2$ (McDonald et al., 1991); and (4) greater concentrations of WSC and lactic acid than observed within time-delayed wrapping treatments, which are required substrates for formation of butyrate. Regardless, these results suggest that baled alfalfa silages may be more susceptible to clostridial fermentation than precisionchopped silages.

In contrast to other fermentation acids, concentrations of isobutyric acid generally increased from minimal and static concentrations $(\leq 0.05 \%)$ with wrapping delays up to $2 \mathrm{~d}$ to $0.11 \%$ after a 3 -d delay. These responses yielded linear $(P<0.001)$ and quadratic $(P=$ 0.021 ) effects of time delay, and bales wrapped without delay contained less isobutyric acid than those with 1-, 2 , or 3 -d delays ( 0.02 vs. $0.06 \% ; P=0.010)$. Isobutyric acid is an oxidation product of valine and has been found in measurable concentrations in clostridial alfalfa silages (Ohshima et al., 1979).

Methanol and Ethanol. Overall, concentrations of methanol were low (overall mean $=0.22 \%$ ), but were greater in silages wrapped after a time delay compared with those fermented without a time delay $(0.22$ vs. $0.19 \% ; P=0.012)$, and increased linearly $(P=0.002)$ in response to wrapping delay. In contrast, concentrations of ethanol were greatest when bales were wrapped without time delay ( 0.29 vs. $0.11 \%: P<0.001)$, and declined with both linear $(P<0.001)$ and quadratic $(P$ $<0.001$ ) effects as time delays were extended to $3 \mathrm{~d}$.

Regressions of Fermentation Products, and $p H$ on Internal Bale Temperature at Wrapping. Concentrations of total fermentation acids and most major individual silage acids declined with internal bale temperature (Figures 3, 4, 5, and 6); however, the relationships were quadratic for total fermentation acids $\left(\mathrm{y}=0.0042 \mathrm{x}^{2}-0.50 \mathrm{x}+17.1 ; \mathrm{R}^{2}=0.725\right.$; $P<0.001)$ and acetic acid $\left(\mathrm{y}=0.0022 \mathrm{x}^{2}-0.24 \mathrm{x}+\right.$ 7.1; $\left.\mathrm{R}^{2}=0.646 ; P<0.001\right)$, but linear for lactic acid $\left(\mathrm{y}=-0.046 \mathrm{x}+3.5 ; \mathrm{R}^{2}=0.663 ; P<0.001\right)$. Concentrations of butyric acid also declined linearly with spontaneous heating $\left(\mathrm{y}=-0.024 \mathrm{x}+1.7 ; \mathrm{R}^{2}=0.375\right.$; $P<0.001$ ); however, responses were more erratic, resulting in a poorer coefficient of determination than observed for total, lactic, or acetic acids. Several minor end products of silage fermentation also exhibited close relationships with internal bale temperature (data not shown). Concentrations of propionic acid declined in a quadratic relationship $\left(\mathrm{y}=0.00040 \mathrm{x}^{2}-0.046 \mathrm{x}+1.4\right.$; $\left.\mathrm{R}^{2}=0.711 ; P<0.001\right)$ with bale temperature, whereas the opposite (positive) response was observed for isobutyric acid $\left(\mathrm{y}=0.00016 \mathrm{x}^{2}-0.013 \mathrm{x}+0.3 ; \mathrm{R}^{2}=0.566\right.$; $P<0.001)$. Although concentrations of ethanol were relatively low $(<0.35 \%)$, this end product exhibited the closest relationship to internal bale temperature of any silage fermentation product evaluated $\left(\mathrm{y}=0.00025 \mathrm{x}^{2}-\right.$ $\left.0.031 \mathrm{x}+1.1 ; \mathrm{R}^{2}=0.856 ; P<0.001\right)$. Overall, the final $\mathrm{pH}$ of baled silages in this study (Figure 7) increased linearly $\left(\mathrm{y}=0.0072+5.4 ; \mathrm{R}^{2}=0.411 ; P<0.001\right)$ with internal bale temperature, which reflects the decreased production of most fermentation acids as a function of spontaneous heating before bale wrapping.

\section{Nutritive Value}

Preensiled. On a preensiled basis, concentrations of whole-plant ash and all fiber components except

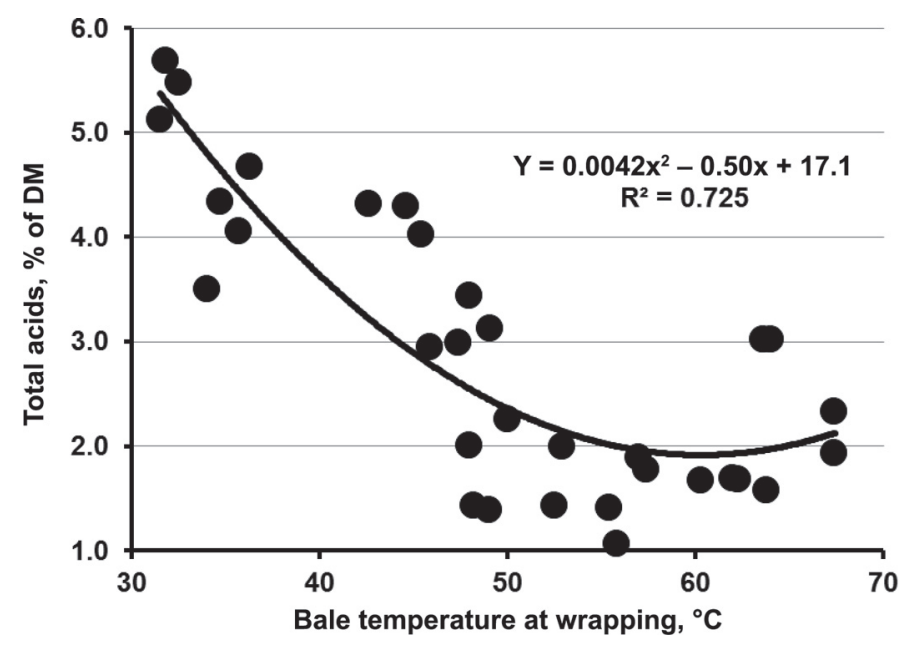

Figure 3. Quadratic regression of total silage fermentation acids after a 97-d storage period on internal bale temperature at the time alfalfa silage bales were wrapped with polyethylene films containing either an $\mathrm{O}_{2}$ barrier or no barrier at Marshfield, Wisconsin. 


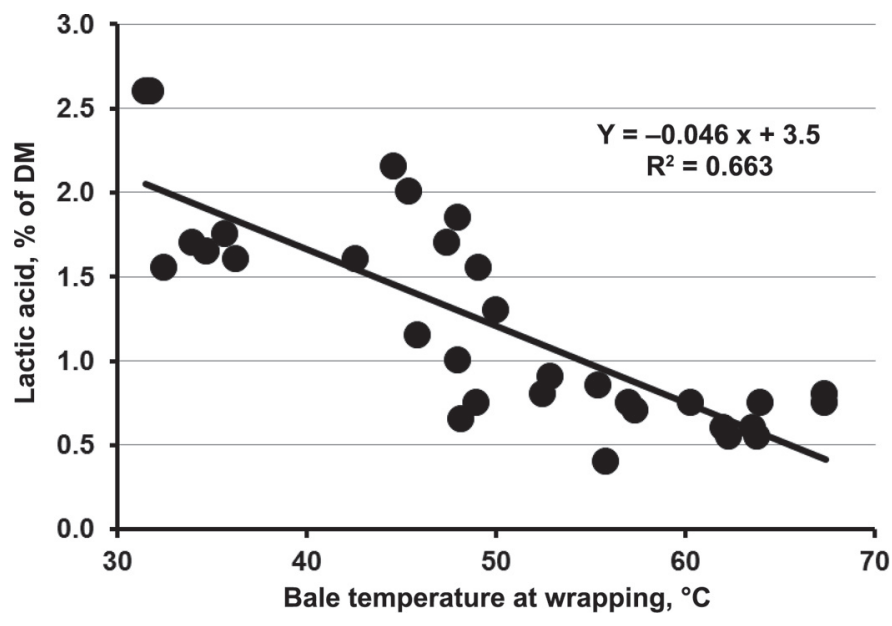

Figure 4. Linear regression of lactic acid after a 97-d storage period on internal bale temperature at the time alfalfa silage bales were wrapped with polyethylene films containing either an $\mathrm{O}_{2}$ barrier or no barrier at Marshfield, Wisconsin.

hemicellulose were greater $(P \leq 0.017)$ after $1-, 2-$, or 3 -d wrapping delays compared with bales wrapped the same day they were baled (Table 5). For each of these nutritional indices, concentration increases also exhibited linear $(P \leq 0.002)$ effects of time delay. Generally, the magnitude of increased NDF, ADF, cellulose, ADL, and ash concentrations was relatively modest across a maximum 3-d wrapping delay, amounting to 2.8, 2.4, $1.5,0.65$, and 0.5 percentage units of DM, respectively. Fiber components and ash are generally considered relatively inert during spontaneous heating, and concentrations typically increase indirectly via oxidation of other often highly digestible forage components, particularly sugars (Rotz and Muck, 1994; Coblentz and Hoffman, 2009b). Hemicellulose exhibited only a quadratic re-

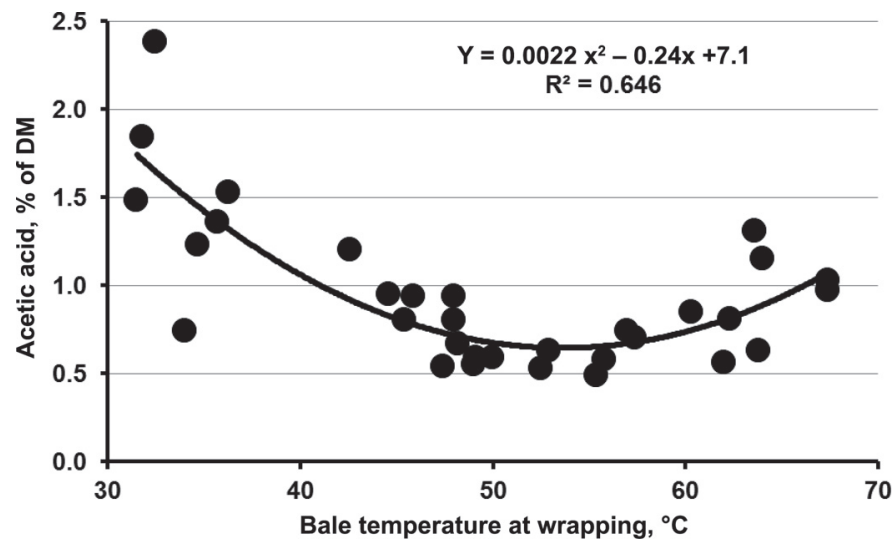

Figure 5. Quadratic regression of acetic acid after a 97-d storage period on internal bale temperature at the time alfalfa silage bales were wrapped with polyethylene films containing either an $\mathrm{O}_{2}$ barrier or no barrier at Marshfield, Wisconsin.

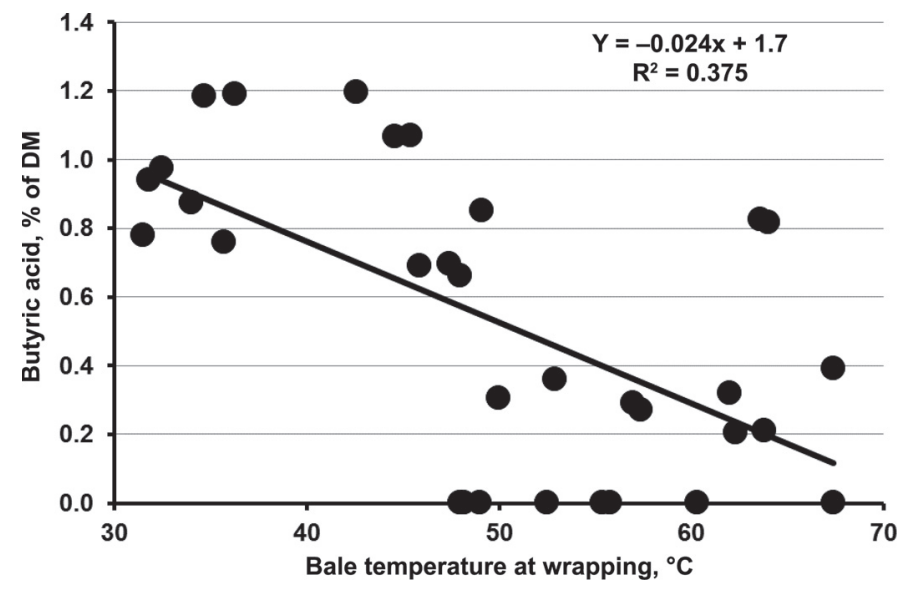

Figure 6. Linear regression of butyric acid after a 97-d storage period on internal bale temperature at the time alfalfa silage bales were wrapped with polyethylene films containing either an $\mathrm{O}_{2}$ barrier or no barrier at Marshfield. Wisconsin.

sponse to wrapping time delays $(P=0.001)$, but no other contrasts were detected for this fiber component $(P \geq 0.111)$. Although it is widely accepted that spontaneous heating of forages increases concentrations of $\mathrm{CP}$ that are insoluble in neutral or acid detergent (Licitra et al., 1996), which also reduces their bioavailability within ruminants (Van Soest, 1982), this was not clearly demonstrated on a pre-ensiled basis. Concentrations of $\mathrm{CP}$ were not affected by wrapping time delay (overall mean $=22.3 \% ; P \geq 0.243)$, whereas NDICP exhibited both linear $(P<0.001)$ and quadratic $(P<0.001)$ effects, and ADICP exhibited only a quadratic $(P=$ 0.027) response. For both NDICP and ADICP, these responses are difficult to relate decisively to the heating associated with wrapping time delays, and the lack of

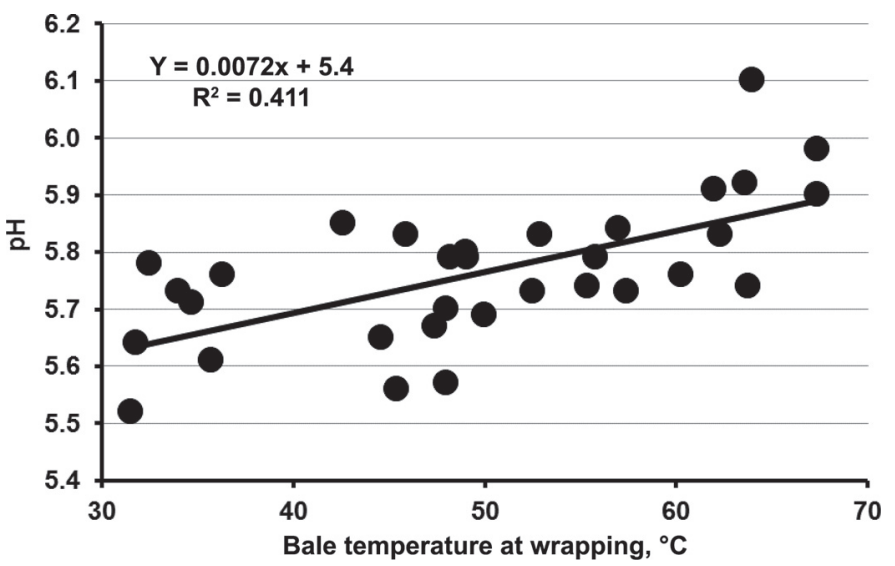

Figure 7. Linear regression of silage $\mathrm{pH}$ after a 97-d storage period on internal bale temperature at the time alfalfa silage bales were wrapped with polyethylene films containing either an $\mathrm{O}_{2}$ barrier or no barrier at Marshfield, Wisconsin. 
Table 5. Nutritive value (\% of DM) of alfalfa silage bales sampled immediately before wrapping in stretch film either with (OB) or without (SUN) an $\mathrm{O}_{2}$-limiting barrier, and after wrapping delays as long as $3 \mathrm{~d}$

\begin{tabular}{|c|c|c|c|c|c|c|c|c|c|c|}
\hline Treatment & $\mathrm{NDF}$ & $\mathrm{ADF}$ & HEMI $^{1}$ & Cellulose & $\mathrm{ADL}$ & Ash & $\mathrm{CP}$ & $\mathrm{NDICP}^{1}$ & $\mathrm{ADICP}^{1}$ & $\mathrm{TDN}^{2}$ \\
\hline \multicolumn{11}{|l|}{ Wrapping delay, d } \\
\hline 0 & 45.7 & 30.3 & 15.4 & 24.0 & 5.82 & 10.7 & 22.1 & 4.82 & 2.06 & 58.3 \\
\hline 2 & 46.6 & 31.5 & 15.0 & 25.0 & 6.11 & 11.0 & 22.2 & 4.69 & 1.93 & 57.3 \\
\hline 3 & 48.5 & 32.7 & 15.8 & 25.5 & 6.47 & 11.2 & 22.3 & 5.50 & 2.21 & 56.0 \\
\hline SEM & 0.42 & 0.48 & 0.36 & 0.32 & 0.145 & 0.12 & 0.16 & 0.142 & 0.075 & 0.32 \\
\hline \multicolumn{11}{|l|}{ Wrap type } \\
\hline SEM & 0.30 & 0.39 & 0.33 & 0.23 & 0.112 & 0.09 & 0.12 & 0.115 & 0.055 & 0.23 \\
\hline \multicolumn{11}{|l|}{ Contrast $^{3}(P>F)$} \\
\hline (1) Delay vs. control & 0.014 & 0.001 & 0.278 & 0.011 & 0.017 & 0.005 & 0.243 & 0.947 & 0.895 & 0.001 \\
\hline (2) Delay: linear & $<0.001$ & $<0.001$ & 0.111 & 0.001 & 0.001 & 0.002 & 0.373 & $<0.001$ & 0.237 & $<0.001$ \\
\hline (3) Delay: quadratic & 0.034 & 0.689 & 0.001 & 0.936 & 0.476 & 0.660 & 0.791 & $<0.001$ & 0.027 & 0.291 \\
\hline (4) OB vs. SUN & 0.984 & 0.992 & 0.989 & 0.677 & 0.282 & 0.713 & 0.662 & 0.791 & 0.538 & 0.520 \\
\hline
\end{tabular}

${ }^{1}$ HEMI, hemicellulose; NDICP, neutral-detergent insoluble CP; ADICP, acid-detergent insoluble CP.

${ }^{2}$ Concentrations of TDN determined per NRC (2001) using the ADL option to calculate truly digestible fiber.

${ }^{3}$ Contrasts: (1) delay vs. control, bales wrapped after a 1-, 2-, or 3-d delay vs. those wrapped the same day they were baled; (2) delay: linear, linear effect of wrapping delay; (3) delay: quadratic, quadratic effect of wrapping delay; and (4) OB vs. SUN wrap.

clarity in responses may be related to the relatively short duration of heating before bales were wrapped in polyethylene film.

\section{Poststorage Nutritive Value}

Residual concentrations of WSC following silage fermentation were greatest when wrapping was delayed by 1,2 , or $3 \mathrm{~d}$ compared with the 0 -d positive control (3.3 vs. $2.8 \% ; P=0.001)$, and increased linearly $(P$ $<0.001)$ with the length of time delay. Generally, the low residual WSC concentrations observed in the $0-d$ positive control bales on a poststorage basis reflect the greater production of fermentation acids in those silages compared with bales with wrapping delays (Table 6). Concentrations of NDF (48.0 vs. $45.4 \% ; P<0.001$ ), hemicellulose (14.5 vs. $12.4 \% ; P<0.001$ ), and ADL (6.14 vs. $5.81 \% ; P=0.005)$ were greater for bales with wrapping delays compared with 0 -d positive controls; in addition, a strong linear $(P<0.001)$ effect was found on time delay for each response variable. This response could be linked directly to the elevated internal bale temperatures associated with wrapping time delay (Figure 8), yielding a positive linear relationship for $\mathrm{NDF}\left(\mathrm{y}=0.14 \mathrm{x}^{2}+40.5 ; \mathrm{R}^{2}=0.666 ; P<0.001\right)$. This response for NDF also is consistent with NDF increases in response to spontaneous heating within large-round bales of alfalfa hay (Coblentz and Hoffman, 2009b). Unlike NDF, hemicellulose, and ADL, concentrations of ADF and cellulose were largely static through a $2-\mathrm{d}$ time delay, but increased thereafter, yielding linear $(P$ $=0.006)$ and quadratic $(P=0.018)$ effects for ADF, but only a quadratic $(P=0.043)$ effect for cellulose.
Concentrations of CP declined linearly $(P=0.007)$ with wrapping delay, but the total range across delay treatments was very narrow (22.4 to $22.0 \%$ ). Residual fiber-associated $\mathrm{CP}$ following extraction in neutral or acid detergent was greater $(P<0.001)$ in bales wrapped after 1-, 2-, or 3-d delays, and also increased linearly $(P<0.001)$ with time delay. A quadratic $(P$ $=0.014)$ effect also was detected for NDICP, which was primarily associated with diminishing proportional responses as time delays were extended; this response was not observed for ADICP $(P=0.437)$. As observed for NDF, NDICP and ADICP were associated directly with the internal bale temperature at the time bales were wrapped, yielding quadratic relationships in both cases (Figures 9 and 10, respectively). This response is consistent with the normal relationship between fiberassociated $\mathrm{CP}$ and heating within forages and feedstuffs (Licitra et al., 1996), and mirror previous responses within large-round bales of alfalfa-orchardgrass hays (Coblentz et al., 2010). Coefficients of determination for these regressions on heating indicated very close associations between NDICP $\left(\mathrm{R}^{2}=0.835\right)$ or ADICP $\left(\mathrm{R}^{2}\right.$ $=0.698)$ and heating in baled silages. Although ADICP increased with heating in silage bales, the percentage of total CP comprised by ADICP ranged between 9.2 and $12.0 \%$, which is within recommended targets for normal silage fermentation (Mahanna and Chase, 2003). Energy density of silages (TDN) was reduced when wrapping was delayed compared with no delay (56.1 vs. $57.3 \% ; P<0.001)$, and these reductions were explained by both linear $(P<0.001)$ and quadratic $(P=0.013)$ effects of time delay. As observed for fiber-associated $\mathrm{CP}$, changes in TDN with heating for these silages (Fig- 

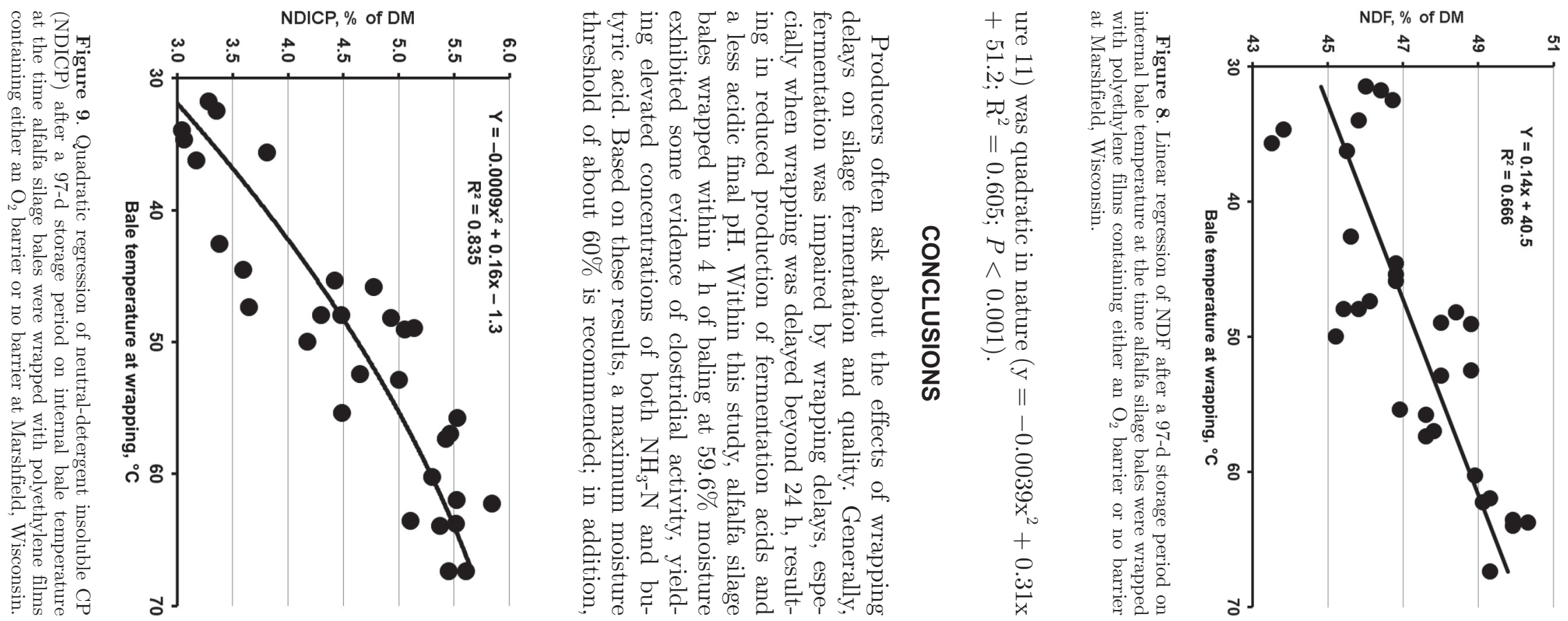

Table 6. Poststorage nutritive value (\% of DM) of alfalfa silage bales wrapped in stretch film either with $(\mathrm{OB})$ or without (SUN) an $\mathrm{O}_{2}$-limiting barrier, and after time delays as long as $3 \mathrm{~d}$

\begin{tabular}{|c|c|c|c|c|c|c|c|c|c|c|c|c|}
\hline Treatment & $\mathrm{WSC}^{1}$ & Starch & NDF & $\mathrm{ADF}$ & HEMI $^{1}$ & Cellulose & $\mathrm{ADL}$ & Ash & $\mathrm{CP}$ & $\mathrm{NDICP}^{1}$ & $\mathrm{ADICP}^{1}$ & $\mathrm{TDN}^{2}$ \\
\hline \multicolumn{13}{|l|}{ Wrapping delay, d } \\
\hline 0 & 2.8 & 0.92 & 45.4 & 33.0 & 12.4 & 26.9 & 5.81 & 11.2 & 22.4 & 3.25 & 2.07 & 57.3 \\
\hline 1 & 3.0 & 0.61 & 46.5 & 33.0 & 13.4 & 26.9 & 5.88 & 11.3 & 22.4 & 4.30 & 2.20 & 56.9 \\
\hline 2 & 3.6 & 0.86 & 47.9 & 32.8 & 15.1 & 26.5 & 5.91 & 11.2 & 22.1 & 5.07 & 2.41 & 56.5 \\
\hline 3 & 3.3 & 0.72 & 49.7 & 34.7 & 15.1 & 27.8 & 6.62 & 11.3 & 22.0 & 5.46 & 2.64 & 54.8 \\
\hline SEM & 0.15 & 0.083 & 0.40 & 0.41 & 0.20 & 0.35 & 0.095 & 0.12 & 0.19 & 0.146 & 0.067 & 0.29 \\
\hline \multicolumn{13}{|l|}{ Wrap type } \\
\hline $\mathrm{OB}$ & 3.2 & 0.74 & 47.4 & 33.3 & 14.1 & 27.0 & 6.09 & 11.3 & 22.2 & 4.54 & 2.32 & 56.3 \\
\hline SUN & 3.1 & 0.82 & 47.3 & 33.4 & 14.0 & 27.0 & 6.02 & 11.2 & 22.3 & 4.50 & 2.34 & 56.5 \\
\hline SEM & 0.12 & 0.059 & 0.28 & 0.31 & 0.14 & 0.28 & 0.067 & 0.08 & 0.17 & 0.114 & 0.048 & 0.22 \\
\hline \multicolumn{13}{|l|}{ Contrast $^{3}(P>F)$} \\
\hline (1) Delay vs. control & 0.001 & 0.049 & $<0.001$ & 0.237 & $<0.001$ & 0.621 & 0.005 & 0.670 & 0.076 & $<0.001$ & $<0.001$ & $<0.001$ \\
\hline (2) Delay: linear & $<0.001$ & 0.323 & $<0.001$ & 0.006 & $<0.001$ & 0.088 & $<0.001$ & 0.911 & 0.007 & $<0.001$ & $<0.001$ & $<0.001$ \\
\hline (3) Delay: quadratic & 0.069 & 0.314 & 0.326 & 0.018 & 0.014 & 0.043 & 0.001 & 0.836 & 0.832 & 0.014 & 0.437 & 0.013 \\
\hline (4) OB vs. SUN & 0.573 & 0.321 & 0.881 & 0.964 & 0.705 & 0.924 & 0.506 & 0.526 & 0.470 & 0.799 & 0.764 & 0.564 \\
\hline
\end{tabular}




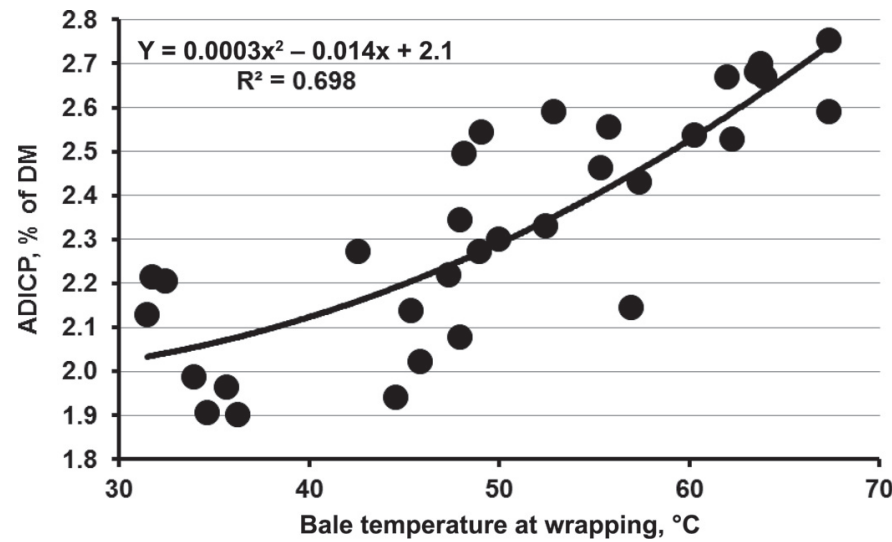

Figure 10. Quadratic regression of acid-detergent insoluble CP (ADICP) after a 97-d storage period on internal bale temperature at the time alfalfa silage bales were wrapped with polyethylene films containing either an $\mathrm{O}_{2}$ barrier or no barrier at Marshfield, Wisconsin.

alfalfa forages wrapped in polyethylene film within this moisture range might be better preserved by including a lactic-acid-producing inoculant to aid fermentation, or by further wilting to about $55 \%$ moisture. Under the management used in this study, inclusion of an OB within the film wrap had no effect on forage nutritive value or silage fermentation characteristics; however, the wrapping protocol imposed (7 layers) could be considered conservative with respect to excluding air and maintaining a good silage fermentation environment. Additional evaluation will be needed to determine if there are benefits from inclusion of an $\mathrm{OB}$ when plastic layers are reduced.

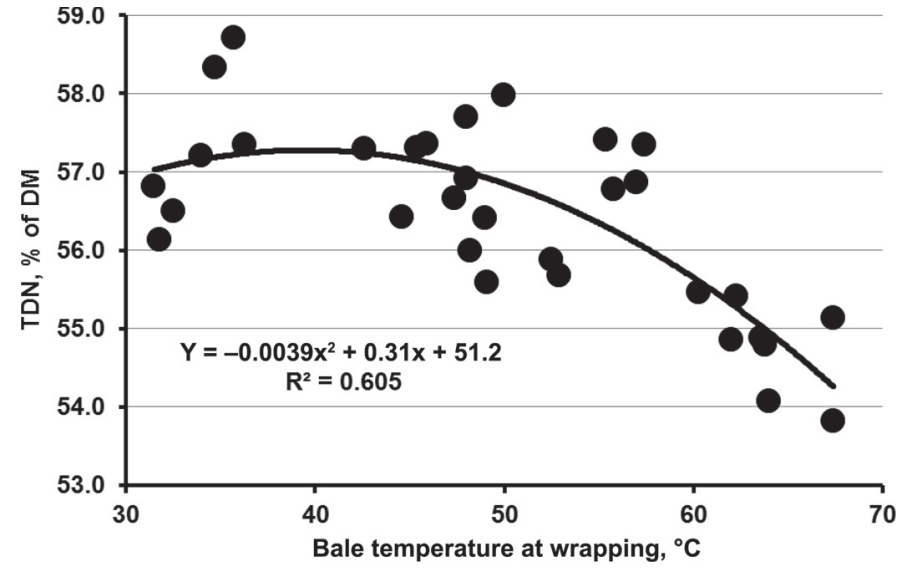

Figure 11. Quadratic regression of TDN after a 97-d storage period on internal bale temperature at the time alfalfa silage bales were wrapped with polyethylene films containing either an $\mathrm{O}_{2}$ barrier or no barrier at Marshfield, Wisconsin.

\section{ACKNOWLEDGMENTS}

Research was supported in part by a generous grant (Agreement \#58-3655-2-512) from Kuraray America Inc., and by appropriated USDA-ARS CRIS funds.

\section{REFERENCES}

AOAC International. 1998. Official Methods of Analysis, AOAC Official Method \#990.03. 16th ed. 4th rev. AOAC Int., Gaithersburg, MD.

Borreani, G., and E. Tabacco. 2008. New oxygen barrier stretch film enhances quality of alfalfa wrapped silage. Agron. J. 100:942-948.

Coblentz, W. K., and P. C. Hoffman. 2009a. Effects of bale moisture and bale diameter on spontaneous heating, dry matter recovery, in vitro true digestibility, and in situ disappearance kinetics of alfalfaorchardgrass hays. J. Dairy Sci. 92:2853-2874.

Coblentz, W. K., and P. C. Hoffman. 2009b. Effects of spontaneous heating on fiber composition, fiber digestibility, and in situ disappearance kinetics of NDF for alfalfa-orchardgrass hays. J. Dairy Sci. 92:2875-2895.

Coblentz, W. K., P. C. Hoffman, and N. P. Martin. 2010. Effects of spontaneous heating on forage protein fractions and in situ disappearance kinetics of crude protein for alfalfa-orchardgrass hays packaged in large-round bales. J. Dairy Sci. 93:1148-1169.

Coblentz, W. K., and R. E. Muck. 2012. Effects of natural and simulated rainfall on indicators of ensilability and nutritive value for wilting alfalfa forages sampled before preservation as silage. J. Dairy Sci. 95:6635-6653.

Coblentz, W. K., R. E. Muck, M. A. Borchardt, S. K. Spencer, W. E. Jokela, M. G. Bertram, and K. P. Coffey. 2014. Effects of dairy slurry on silage fermentation characteristics and nutritive value of alfalfa. J. Dairy Sci. 97:7197-7211.

Dubois, M., K. A. Gilles, J. K. Hamilton, P. A. Rebers, and F. Smith. 1956. Colorimetric method for determination of sugars and related substances. Anal. Chem. 28:350-356.

Han, K. J., M. Collins, E. S. Vanzant, and C. T. Dougherty. 2004. Bale density and moisture effects on alfalfa round bale silage. Crop Sci. 44:914-919.

Hancock, D. W., and M. Collins. 2006. Forage preservation method influences alfalfa nutritive value and feeding characteristics. Crop Sci. 46:688-694.

Jennings, J. A. 2011. Bales silage for livestock. \#FSA3051-PD4-11RV. University of Arkansas Cooperative Extension Service, Little Rock, AR.

Licitra, G., T. M. Hernandez, and P. J. Van Soest. 1996. Standardization of procedures for nitrogen fractionation of ruminant feeds. Anim. Feed Sci. Technol. 57:347-358.

Mahanna, B., and L. E. Chase. 2003. Practical applications and solutions to silage problems. Pages $855-895$ in Silage Science and Technology. D. R. Buxton, R. E. Muck, and J. H. Harrison, ed. American Society of Agronomy, Crop Science Society of America, and Soil Science Society of America, Madison, WI.

McBeth, L. J., K. P. Coffey, W. K. Coblentz, J. E. Turner, D. A. Scarbrough, C. R. Bailey, and M. R. Stivarius. 2001. Impact of heating degree-day accumulation during bermudagrass hay storage on nutrient utilization by lambs. J. Anim. Sci. 79:2698-2703.

McCormick, M. E., G. J. Cuomo, and D. C. Blouin. 1998. Annual ryegrass stored as balage, haylage, or hay for lactating dairy cows. J. Prod. Agric. 11:293-300.

McDonald, P., and R. A. Edwards. 1976. The influence of conservation methods on digestion and utilization of forages by ruminants. Proc. Nutr. Soc. 35:201-211.

McDonald, P., A. R. Henderson, and S. J. E. Heron. 1991. The Biochemistry of Silage. 2nd ed. Chalcombe Publications, Marlow, Buckinghamshire, UK 
Moshtaghi Nia, S. A., and K. M. Wittenburg. 2000. Effect of delayed wrapping on preservation and quality of whole crop barley forage ensiled as large bales. Can. J. Anim. Sci. 80:145-151.

Muck, R. E. 1990. Dry matter level effects on alfalfa silage quality. II. Fermentation products and starch hydrolysis. Trans. ASAE 33:373-381.

Muck, R. E., L. E. Moser, and R. E. Pitt. 2003. Postharvest factors affecting ensiling. Pages 251-304 in Silage Science and Technology. D. R. Buxton, R. E. Muck, and J. H. Harrison, ed. American Society of Agronomy, Crop Science Society of America, and Soil Science Society of America, Madison, WI.

Muck, R. E., and R. P. Walgenbach. 1985. Variations in alfalfa buffering capacity. ASAE Paper No. 85-1535. Am. Soc. Agric. Eng., St. Joseph, MI.

Nicholson, J. W. G., R. E. McQueen, E. Charmley, and R. S. Bush. 1991. Forage conservation in round bales or silage: Effect on ensiling characteristics and animal performance. Can. J. Anim. Sci. $71: 1167-1180$.

NRC. 2001. Nutrient Requirements of Dairy Cattle. 7th rev. ed. National Academy Press, Washington, DC.

Ohshima, M., P. McDonald, and T. Acamovic. 1979. Changes during ensilage in the nitrogenous components of fresh and additive treated ryegrass and lucerne. J. Sci. Food Agric. 30:97-106.

Rotz, C. A., and R. E. Muck. 1994. Changes in forage quality during harvest and storage. Pages 828-868 in Forage Quality, Evaluation, and Utilization. Proc. Natl. Conf. on Forage Quality, Evaluation, and Utilization, Lincoln, NE. 13-15 Apr. 1994. G. C. Fahey, M. Collins, D. R. Mertens, and L. E. Moser, ed. American Society of Agronomy, Crop Science Society of America, and Soil Science Society of America, Madison, WI.

Savoie, P., and J. C. Jofriet. 2003. Silage storage. Pages 405-468 in Silage Science and Technology. D. R. Buxton, R. E. Muck, and J. H. Harrison, ed. American Society of Agronomy, Crop Science Society of America, and Soil Science Society of America, Madison, WI.

Shinners, K. J. 2003. Engineering principles of silage harvesting management. Pages 361-404 in Silage Science and Technology. D. R. Buxton, R. E. Muck, and J. H. Harrison, ed. American Society of Agronomy, Crop Science Society of America, and Soil Science Society of America, Madison, WI.

Van Soest, P. J. 1982. Nutritional Ecology of the Ruminant. Cornell Univ. Press, Ithaca, NY.

Van Soest, P. J., J. B. Robertson, and B. A. Lewis. 1991. Methods for dietary fiber, neutral detergent fiber, and nonstarch polysaccharides in relation to animal nutrition. J. Dairy Sci. 74:3583-3597.

Weiss, W. P. H. R. Conrad, and N. R. Pierre. 1992. A theoreticallybased model for predicting total digestible nutrient values of forages and concentrates. Anim. Feed Sci. Technol. 39:95-110.

YSI. 2000. YSI 2700 Select Biochemistry Analyzer. User's Manual. YSI Inc., Yellow Springs, OH. 